\title{
The Cytotoxic and Anti-proliferative Effects of 3-Hydrogenkwadaphnin in K562 and Jurkat Cells Is Reduced by Guanosine
}

\author{
Mohammad Amin Moosavi, Razieh Yazdanparast* and Mohammad Hasan Sanati \\ Institute of Biochemistry and Biophysics, P. O. Box. 13145 - 1384 University of Tehran, Tehran, Iran \\ National Research Center for Genetic Engineering and Biotechnology, P. O. Box. 14155 - 6343 Tehran, Iran
}

Received 7 February 2005, Accepted 2 March 2005

\begin{abstract}
3-hydrogenwadaphnin (3-HK) is a new daphnane-type diterpene ester isolated from Dendrostellera lessertii with strong anti-tumoral activity in animal models and in cultures. Here, prolonged effects of this new agent on proliferation and viability of several different cancerous cell lines were evaluated. Using $\left[{ }^{3} \mathrm{H}\right]$ thymidine incorporation, it was found that the drug inhibited cell proliferation and induced G1/S cell cycle arrest in leukemic cells $24 \mathrm{~h}$ after a single dose treatment. The cell viability of Jurkat cells was also decreased by almost $10 \%, 31 \%$ and $40 \%$ after a single dose treatment $(7.5 \mathrm{nM})$ at 24,48 and $72 \mathrm{~h}$, respectively. The drug-treated cells were stained with acridine orange/ ethidium bromide to document the chromatin condensation and DNA fragmentation. These observations were further confirmed by detection of DNA laddering pattern in the agarose gel electrophoresis of the extracted DNA from the treated cells. Treatment of $\mathrm{K562}$ cells with the drug at 7.5, 15 and $30 \mathrm{nM}$ caused apoptosis in $25 \%, 45 \%$ and $65 \%$ of the cells, respectively. Exogenous addition of 25-50 $\mu \mathrm{M}$ guanosine and/or deoxyguanosine to the cell culture of the drug-treated cells restored DNA synthesis, released cell arrest at G1/S checkpoint and decreased the apoptotic cell death caused by the drug. These observations were not made using adenosine. However, the drug effects on $\mathrm{K562}$ cells were potentiated by hypoxanthine. Based on these observations, perturbation of GTP metabolism is considered as one of the main reasons for apoptotic cell death by 3 HK.
\end{abstract}

Keywords: Apoptosis, Cell cycle arrest, Dendrostellera lessertii, DNA synthesis, Guanylate metabolism, 3-Hydrogenkwadaphnin

\footnotetext{
*To whom correspondence should be addressed.

Tel: +98-21-6956976; Fax: +98-21-6404680

E-mail: yazdan@ibb.ut.ac.ir
}

\section{Introduction}

The search for new pharmacologically active drugs from natural sources has led to the discovery of many useful drugs and approximately $60 \%$ of the anti-tumor agents which are clinically used, or they are in the late stages of development, are from natural sources (Shu, 1998). Indeed, today's medical world is highly dependent on several natural products such as taxol, vincritin and comptithecin in fighting different kinds of cancer (Pezzuto, 1997). Along this line, plant-derived compounds have great potential to be developed into anti-cancer drugs because of their multiple mechanisms and low side effects (Yoshida et al., 1996). It has become increasingly evident that apoptosis is an important mode of action for many anti-tumor drugs so that modulation of cell apoptosis seems to be a reliable approach for the evaluation of the potency of newly discovered compounds as effective anti-cancer agents, particularly when it is specifically achieved (Yoshida et al., 1996; Taraphdar et al., 2001). Apoptosis is a form of cell death that allows for elimination of damaged or unwanted cells without damage to the organisms. It has been originally defined by morphological criteria such as cellular shrinkage, chromatin condensation and fragmentation of the cells into apoptotic bodies. A central role in apoptosis is played by caspases, a family of proteases responsible for many of morphological as well as biochemical changes observed in apoptotic cells (Earnshaw et al., 1999).

In this respect, our lab has initiated screening programs on new anti-cancer agents from Iranian medicinal plants with emphasis on Thymelaeaceae family. Various species of Thymelaeaceae family have been used to treat cancer since 200 A.D. We observed that methanol extracts of two species: Dendrostellera lessertii and Daphne mucronata, have potent anti-cancer property in different human leukemic cell lines and in animal models (Hedayati et al., 2002; Sadeghi and Yazdanparast, 2003; Yazdanparast et al., 2003). These cytotocixity effects were shown to be related to their active compounds: 3-hydrogenkwadaphnin (Fig. 1) and gnidilatimonoein, 


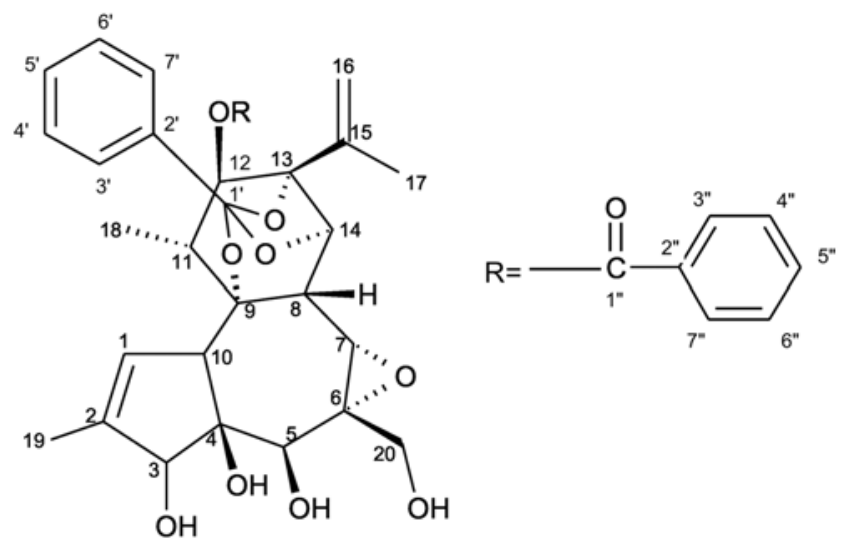

Fig. 1. Structures of 3-hydrogenkwadaphnin (3-HK).

respectively (Mianabadi et al., 2003; Yazdanparast et al., 2003; Mianabadi and Yazdanparast, 2004; Yazdanparast and Mianabadi, 2004). Both compounds are ortho-esters bearing daphnane-type diterpenes with an isopropylene side chain at $\mathrm{C}_{13}$. Indeed, daphnane-type diterpene esters which posses an isopropylene side chain at $\mathrm{C}_{13}$ have previously been reported to have anti-leukemic activity (Hall et al., 1982). Further studies with K562 leukemic cell line revealed that gnidilatimonoein (Sadeghi and Yazdanparast, 2004) and 3-HK (submitted) induce G1/S cell cycle arrest and inhibited nucleic acid synthesis. In addition, the activity of inosine monophosphate dehydrogenase (IMPDH; EC1.1.1.205), the rate-limiting enzyme in the biosynthetic pathway of guanine nucleotides from IMP, was significantly reduced by gnidilatimonoein (Sadeghi and Yazdanparast, 2004) and 3-HK (submitted). The effects of IMPDH inhibition and consequent guanine nucleotide depletion have been investigated in many cell culture systems using different drugs (Ahmed and Weidermann, 1995) which induce cell-cycle arrest in late G1, inhibition of nucleic acid synthesis, differentiation and recently induction of apoptosis (Jayaram et al., 1992; Vitale et al., 1997; Laliberte et al., 1998; Jayaram et al., 1999; Metz et al., 2001). The cause(s) of all of the above effects seems to be GTP depletion (Li et al., 1998; Zimmerman et al., 1998; Gu et al., 2003).

According to literature, other daphnane-type diterpene esters such as genkwadaphnin, yuanhuacine and genidilatidin, with similar structures, have potent anti-leukemic activities similar to our isolated compounds. In addition their inhibitory effects against IMPDH have also been reported (Hall et al., 1982; Liou et al., 1982). However, the exact molecular mechanism(s) of their anti-leukemic effects have not been studied. Therefore, it is interesting to investigate the mechanism(s) of anti-leukemic effects of the diterpene esters with focus on their relationship with IMPDH inhibition.

To get a better understanding about the mechanism of action of $3-\mathrm{HK}$, and to elucidate the relation of DNA synthesis, G1 cell cycle arrest and apoptosis to the druginduced IMPDH inhibition, we examined the involvement of guanine nucleotides and showed that the effects of the drug on the cells are mainly related to GTP depletion.

\section{Materials and Methods}

Materials The cell culture medium (RPMI 1640), fetal bovina serum (FBS) and penicillin-streptomycin were purchased from Gibco BRL (Life technolologies, Paisley, Scotland). The culture plates were obtained from Nunc (Roskilde, Denmark). Cell lines were obtained from Pasteur Institute of Iran (Tehran, Iran). MTT [3-(4,5'-dimethyltiazol-2-yl)-2,5-diphenyltetrazolium bromide] and actinomycine D were purchased from Sigma. Chem. Co. (Munich, Germany). Chloroform, isoamyl alcohol, isopropanol and phenol were obtained from Merck (Darmstadt, Germany). [ $\left.{ }^{3} \mathrm{H}\right]$ thymidine was purchased from Amersham Pharmacia Biotech (Bucks, UK). Guanosine, deoxyguanosine and adenosine were purchased from Aldrich Chemical Co. Ltd (Gillingham, England). RNase A (DNase free), ethidium bromide and acridine orange were obtained from Pharmacia LKB Biotechnology AB Uppsala, Sweden.

Cell culture Molt4, HL-60, HepG2, MCF7, K562 and Jurkat cell lines were cultured in RPMI 1640 medium supplemented with FBS $(10 \%, \mathrm{v} / \mathrm{v})$, streptomycin $(100 \mu \mathrm{g} / \mathrm{ml})$, and penicillin $(100 \mathrm{U} / \mathrm{ml})$. Cell numbers were assessed using a hemocytometer and the ability of the cells to exclude trypan blue.

Cell viability assay The number of viable cells was estimated by MTT assay (Vistica et al., 1991; Zhang et al., 2000). Briefly, the cells $\left(5 \times 10^{4}\right.$ cells/well $)$ were seeded in flat-bottom $96-$ well plates. After culturing for $24 \mathrm{~h}$, different concentrations of $3-\mathrm{HK}$ were added to each well for various time intervals and $10 \mu \mathrm{l} \mathrm{MTT}(5 \mathrm{mg} /$ $\mathrm{ml}$ ) was added to each well $4 \mathrm{~h}$ before harvesting. The reaction was stopped by adding $100 \mu \mathrm{l}$ of $0.04 \mathrm{~N} \mathrm{HCl}$ in isopropanol and the absorbance values at $570 \mathrm{~nm}$ were determined on a multiwell plate reader (Elx 800 Microplate Reader, Bio-TEK).

DNA synthesis DNA synthesis was estimated by measuring $\left[{ }^{3} \mathrm{H}\right]$ thymidine incorporation (Nio et al., 1990; Yamada et al., 2002). Briefly, $2 \times 10^{4}$ cells were seeded per well and different concentrations of 3-HK were added to each well and incubated for various time intervals. $\left[{ }^{3} \mathrm{H}\right]$ thymidine $(1 \mu \mathrm{Ci} /$ well $)$ was included during the last $3 \mathrm{~h}$. After drying at room temperature, the glass fiber filters were placed into counting vials with $5 \mathrm{ml}$ of the scintillation fluid and their radioactivity was measured in a liquid scintillation counter (Rackbeta, LKB) as a measure of thymidine incorporation into DNA. The extent of inhibition of DNA synthesis was determined by the following equation: \%inhibition $=[1-$ test $(\mathrm{cpm})]$ $/[$ control $(\mathrm{cpm})] \times 100$.

Flow cytometry analyses DNA content was analyzed on an EPICS II flow cytometer (Beckman counter, France) according to the established procedure (Papazisis et al., 2000). Jurkat cells $(1 \times$ $10^{6}$ cells/well) were seeded into culture dishes $24 \mathrm{~h}$ prior to treatments. The cells were harvested after $24 \mathrm{~h}$ of treatment with 3HK $(7.5 \mathrm{nM})$ in presence and absence of $25 \mu \mathrm{M}$ guanosine. Cells were washed twice with PBS (Phosphate Buffer Saline), fixed in 
$70 \%$ ethanol, and kept at $-20^{\circ} \mathrm{C}$ until analysis. The cells were then stained with $20 \mu \mathrm{g} / \mathrm{ml}$ propidium iodide containing $20 \mu \mathrm{g} / \mathrm{ml}$ RNase (DNase free) for $2 \mathrm{~h}$. The stained cells were analyzed by flow cytometry. The population of G0/G1, S, and G2/M were determined using Mulicycle Cell Cycle Software. The results are expressed as percentage of the cells in each phase.

DNA fragmentation assay DNA fragmentation in K562 cells was measured after extraction of DNA from a constant number of cells. After treatment of K562 cells for $72 \mathrm{~h}, 1 \times 10^{6}$ cells were collected and washed twice with cold PBS, resuspended in $100 \mu \mathrm{l}$ lytic solution (10 mM EDTA, $50 \mathrm{mM}$ Tris, pH 8, 0.5\% SDS, 100 $\mathrm{mM} \mathrm{NaCl})$ and incubated with proteinase $\mathrm{K}(200 \mu \mathrm{g} / \mathrm{ml})$ at $50^{\circ} \mathrm{C}$ overnight. DNA was extracted with phenol/chloroform/isoamyl alcohol $(25: 24: 1)$, washed with ethanol, resuspend in TE (TrisEDTA) buffer, and separated by electrophoresis in a $2 \%$ agarose gel containing ethidium bromide $(0.5 \mu \mathrm{g} / \mathrm{ml})$. The gel was photographed under UV transillumination. DNA from Jurkat cells was measured by Quick Apoptotic DNA Ladder Detection Kit from Biosource (USA) according to manufacturer procedures. Briefly, soluble DNA fragments were extracted from the treated Jurkat cells and loaded onto a $1 \%$ agarose gel containing $0.5 \mu \mathrm{g} / \mathrm{ml}$ ethidium bromide in both gel and the running buffer $(1 \times \mathrm{TBE})$. The gel was run at $5 \mathrm{~V} /$ $\mathrm{cm}$ for 2 hours.

Morphological study of the apoptotic cells Apoptosis was determined morphologically after staining with acridine orange/ ethidium bromide by fluorescence microscopy (Saydam et al., 2003). Cells were washed in cold PBS and adjusted to a cell density of $1 \times 10^{6} \mathrm{cell} / \mathrm{ml}$ of PBS. Acridine orange/ethidium bromide solution $(1: 1, \mathrm{v} / \mathrm{v})$ was added to the cell suspension in a final concentration of $100 \mu \mathrm{g} / \mathrm{ml}$. The cellular morphology was evaluated by Axoscope 2 plus fluorescence microscopy from ZEISS (Oberkochen, Germany).

\section{Results}

The cytotoxic effects of $3-\mathrm{HK}$ in different tumor cell lines The results presented in Table 1, clearly indicate that the new diterpene ester had potent cytotoxic activity toward a panel of six human cancerous cell lines used in this investigation. The $\mathrm{IC}_{50}$, determined $48 \mathrm{~h}$ after a single dose treatment of each cell type, ranges between 10-25 nM. Apparently, the potency of the compound is not related to p53 status of cells since K562, HL-60 and HepG2 cells lacks active p53 protein (Pipano et al., 2002). Also the activity of the new diterpene ester is very noticeable in K562 cells which are believed to be resistant to many anti-cancer drugs (McGahon et al., 1994). Regarding the $\mathrm{IC}_{50}$ values, the rest of our investigation was mostly done using the most sensitive (Jurkat) and the so called drug resistant K562 cells.

The acute and long-term effects of $3-\mathrm{HK}$ on viability of K562 and Jurkat cells Treatment of K562 and Jurkat cells with different concentrations of 3-HK for long times resulted in cell death. The cytotoxic evaluation by MTT assay
Table 1. Cytotoxic effects of $3-\mathrm{HK}$ in six different cancer cell lines. The $\mathrm{IC}_{50} \mathrm{~s}$ have been established $48 \mathrm{~h}$ after the drug treatment as explained in materials and methods. Each measurement represents the average of triplicate experiment $\pm \operatorname{SEM}(p<0.05)$

\begin{tabular}{cc}
\hline Cell type & $\mathrm{IC}_{50}(\mathrm{nM})$ \\
\hline HepG2 & $25.0 \pm 0.1$ \\
MCF7 & $20.0 \pm 0.2$ \\
K562 & $15.0 \pm 0.4$ \\
Molt4 & $13.0 \pm 0.8$ \\
HL-60 & $12.0 \pm 0.7$ \\
Jurkat & $10.0 \pm 0.5$ \\
\hline
\end{tabular}
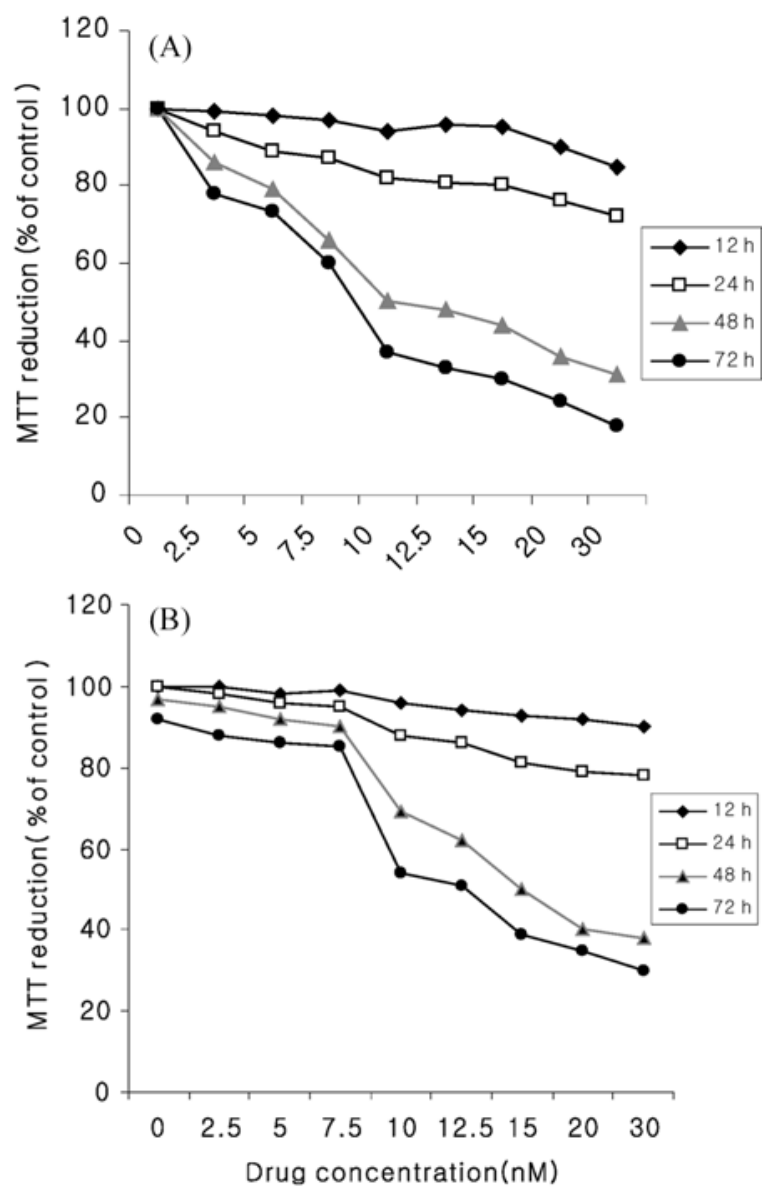

Fig. 2. Prolonged 3-HK treatment induces cell death. Exponentially growing Jurkat (A) and K562 (B) cells in the 96-well plates were treated with a single dose of the drug at different concentrations for various time intervals and cell viability was determined by MTT assays. The results represent those of a single typical experiment.

indicated that no significant changes in the extent of formazan production occurred in K562 and Jurkat cells $12 \mathrm{~h}$ after treatment with $2.5-30 \mathrm{nM}$ of the drug (Fig. 2) and a slight decrease occurs after $24 \mathrm{~h}$. However, after $48 \mathrm{~h}$ of treatment, the cell viability was reduced by $50 \%$ at $15 \mathrm{nM}$ and $10 \mathrm{nM}$ of the drug in K562 and Jurkat cells, respectively. Treatment for 


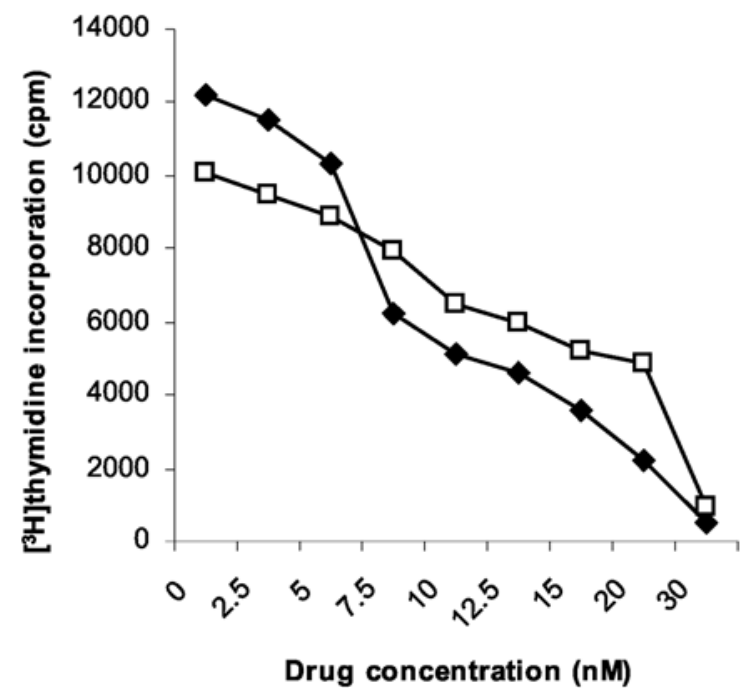

Fig. 3. Effects of different concentrations of $3-\mathrm{HK}$ on $\left[{ }^{3} \mathrm{H}\right]$ thymidine incorporation into DNA of Jurkat $(\diamond)$ and K562 $(\square)$ cells. The cells were treated with different concentrations of the drug for 24 $\mathrm{h}$ followed by the addition of $\left[{ }^{3} \mathrm{H}\right]$ thymidine $(1 \mu \mathrm{Ci} /$ well $)$ three hours before the cell harvesting. The results represent those of a single typical experiment.

longer periods of time resulted in a massive cell death even at low concentrations of $3-\mathrm{HK}$.

Effects of 3-HK on DNA synthesis in K562 and Jurkat cells The anti-proliferative activity of the 3-HK was evaluated by measuring its effects on the extent of DNA synthesis in K562 and Jurkat cell lines. As shown in Fig. 3, the extent of $\left[{ }^{3} \mathrm{H}\right]$ thymidine incorporation into DNA decreases in a dose dependent manner. In other words, at 7.5, 10.0, 15.0 and $30.0 \mathrm{nM}$ concentrations, DNA synthesis is inhibited by $21 \%, 35 \%, 48 \%$ and $90 \%$ in K562 cells and by $43 \%, 57 \%$, $70 \%$ and $95 \%$ in Jurkat cells. Indeed these cells are very sensitive to DNA synthesis inhibition, so that in Jurkat cells DNA synthesis inhibition occur as early as $3 \mathrm{~h}$ after drug treatment and reduced nearly up to $50 \%$ after $24 \mathrm{~h}$ at $7.5 \mathrm{nM}$ drug concentration (data not shown).
Effects of 3-HK on cell cycle progression of Jurkat cells Based on Fig. 3 the drug, even at low concentrations, had potent effect on DNA synthesis after $24 \mathrm{~h}$ of treatment with a single dose. However, the cells viability did not significantly varied under the same experimental conditions (Fig. 2A). In order to get a better understanding of the anti-proliferative activity of the drug, the growth pattern of the treated and untreated Jurkat cells were investigated using flow cytometry. Twenty-four hours after seeding, the Jurkat cells were treated with a single dose $(7.5 \mathrm{nM})$ of $3-\mathrm{HK}$. The cells were incubated for $24 \mathrm{~h}$ at $37^{\circ} \mathrm{C}$ followed by cell cycle analysis with respect to the corresponding control cells. The cell growth distribution in the control sample was $28 \%$ in G1 phase, $43 \%$ in $\mathrm{S}$ phase and $29 \%$ in $\mathrm{G} 2$ phase. This distribution changed upon treatment and resulted in the accumulation of $41 \%$ of cells in G1 phase which accompanied by a slight compensatory decrease in the proportion of S and G2/M cells. (Fig. 4, A and B). However, after this time point (24 h) the cells at G1 phase decreased and a sub-G1 peak was appeared (data not shown).

Effects of guanine nucleotides on DNA synthesis, cell cycle progression and cell viability According to the literature, both guanosine and deoxyguanosine at $25 \mu \mathrm{M}$ are capable of increasing the pool size of guanine nucleotides with the lowest anti-proliferative effects in Jurkat cells (Batiuk et al., 2001). In our investigation, addition of guanosine $(25 \mu \mathrm{M})$ to the $3-\mathrm{HK}$ treated Jurkat cells removed the G1/S arrest and resulted in cell accumulation in $\mathrm{S}$ phase of the progression cycle (Fig. 4C). These results are similar to the effect of guanosine on cell cycle progression in human $\mathrm{T}$ lymphocytes (Laliberte et al., 1998). Inhibition of DNA synthesis and cytotoxicity (Table 2) in the drug-treated cells were also impeded upon guanosine addition. According to these data, both guanosine and deoxyguanosine, at $25 \mu \mathrm{M}$ concentrations, restored the DNA synthesis in the drug treated cells by $97 \%$ and $64 \%$, respectively. However, adenosine at various concentrations (25-50 $\mu \mathrm{M})$ did not show such a preventive effect (Table 2). At higher concentrations both guanosine and deoxyguanosine were also capable of restoring DNA synthesis in the drug

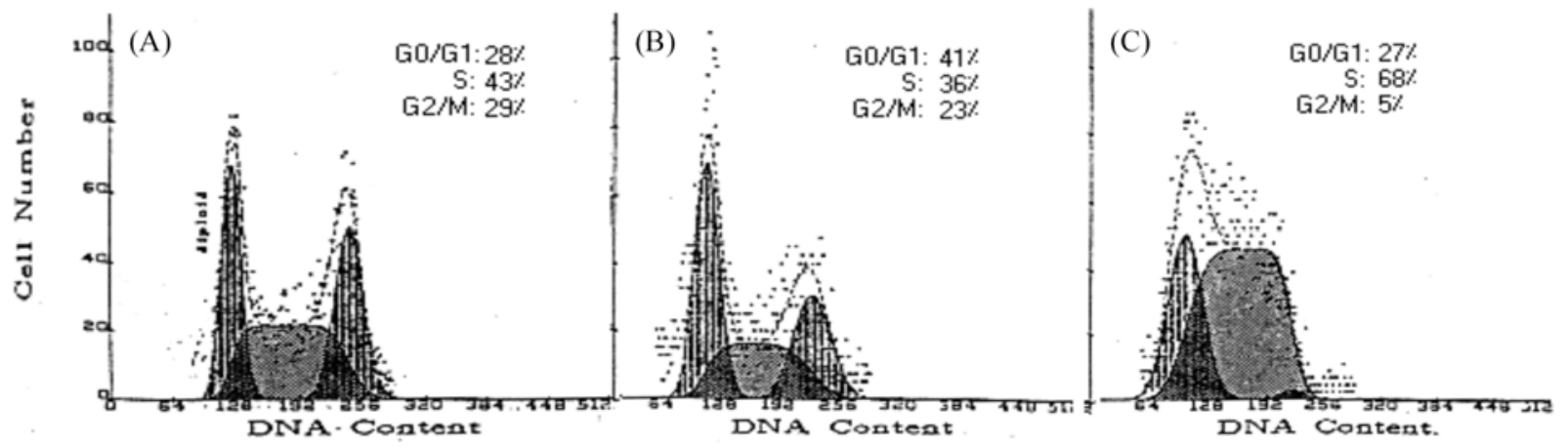

Fig. 4. Cell cycle progression in the absence (A) and the presence of 3-HK (B and C). Jurkat cells were treated with $7.5 \mathrm{nM} 3-$ hydrogenkwadaphnin for $24 \mathrm{~h}$. Simultaneous addition of the drug and guanosine $(25 \mu \mathrm{M}, \mathrm{C})$ result in elimination of G1/S cell cycle arrest and accumulation of the treated cells in the $\mathrm{S}$ phase of the progression cycle. 
Table 2. Effects of nucleosides on metabolic viability and DNA synthesis of Jurkat cells. The Jurkat cells $\left(5 \times 10^{4} /\right.$ well $)$ were culture in 96-well plates and were exposed to $7.5 \mathrm{nM}$ of the drug alone or combined with other agents in the culture medium for $24 \mathrm{~h}$ (DNA synthesis) or $48 \mathrm{~h}$ (MTT assay) as explained in materials and methods. Each measurement represents the average of three analyses $\pm \operatorname{SEM}(p<0.05)$

\begin{tabular}{lcccc}
\hline \multirow{2}{*}{ Addition } & \multicolumn{2}{c}{ Formazan production $(\%$ of control) } & \multicolumn{2}{c}{$\left[{ }^{3} \mathrm{H}\right]$ thymidine incorporation $(\%$ of control) } \\
\cline { 2 - 5 } & \multicolumn{1}{c}{ Control } & Drug-treated & Control & Drug-treated \\
\hline None & $100.00 \pm 0.00$ & $50.00 \pm 0.30$ & $100.00 \pm 0.00$ & $57.00 \pm 0.90$ \\
Guanosine $(25 \mu \mathrm{M})$ & $104.00 \pm 1.30$ & $90.00 \pm 0.60$ & $109.00 \pm 0.50$ & $97.00 \pm 0.20$ \\
Deoxyguanosine $(25 \mu \mathrm{M})$ & $89.00 \pm 0.09$ & $60.00 \pm 0.20$ & $91.00 \pm 0.80$ & $64.00 \pm 0.10$ \\
Adenosine $(25 \mu \mathrm{M})$ & $92.00 \pm 0.70$ & $48.00 \pm 0.06$ & $93.00 \pm 1.30$ & $44.00 \pm 1.50$ \\
Hypoxanthine $(100 \mu \mathrm{M})$ & $94.00 \pm 0.80$ & $31.00 \pm 0.30$ & $\mathrm{ND}$ & $\mathrm{ND}$ \\
Actinomycine $\mathrm{D}(0.05 \mu \mathrm{M})$ & $96.00 \pm 0.1 .2$ & $69.00 \pm 0.88$ & $97.00 \pm .003$ & $79.00 \pm .040$ \\
\hline
\end{tabular}
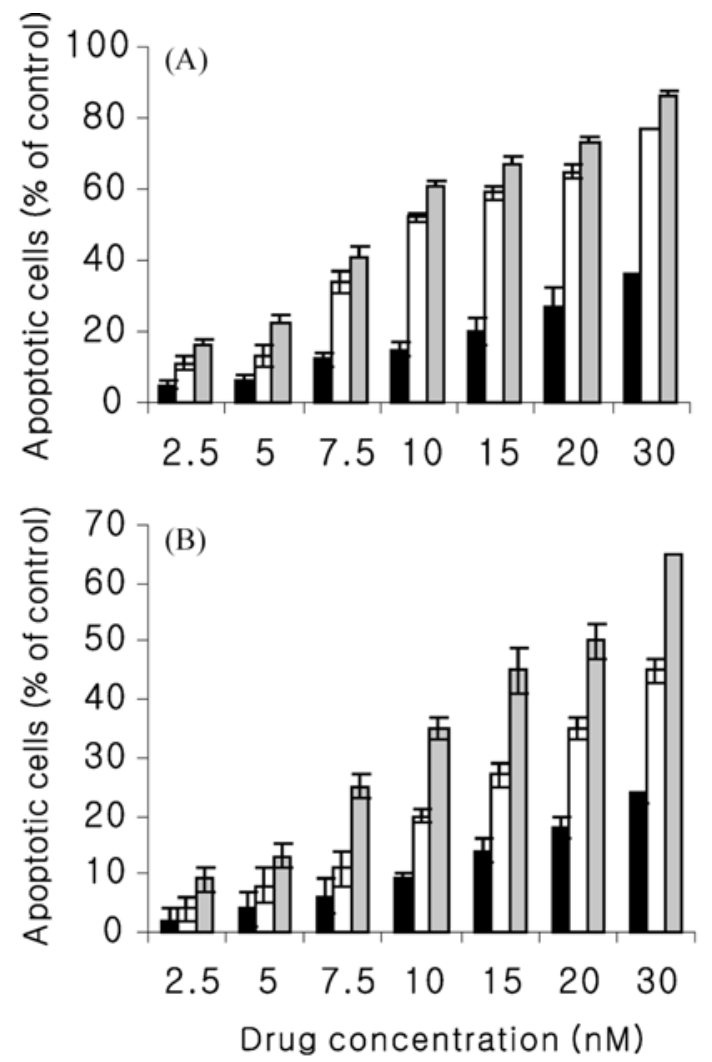

Fig. 5. Effect of different concentrations of $3-\mathrm{HK}$ on the induction of apoptosis at various time intervals. The Jurkat cells $\left(1 \times 10^{6} /\right.$ well, A) and K562 cells $\left(1 \times 10^{6} /\right.$ well, B) treated with a single dose of the drug ranging between $2.5-30 \mathrm{nM}$. At different time intervals, the cells were harvested and stained with Acridine orange/Ethidium bromide. At least 200 cells were counted in each experiment by fluorescence microscopy. The columns show the treated cells after $24 \mathrm{~h}(\boldsymbol{\square}), 48 \mathrm{~h}(\square)$ and $72 \mathrm{~h}($ (:III). The results present the average of triplicate counting \pm S.E.M $(p<0.05)$.

treated K562 cells. In this cell line, guanosine and deoxyguanosine at $50 \mu \mathrm{M}$ restored DNA synthesis by $88 \%$ and $55 \%$ of the control cells, respectively (data not shown). These results indicate that in both cell lines guanosine almost completely and deoxyguanosine partially restored DNA

(A)
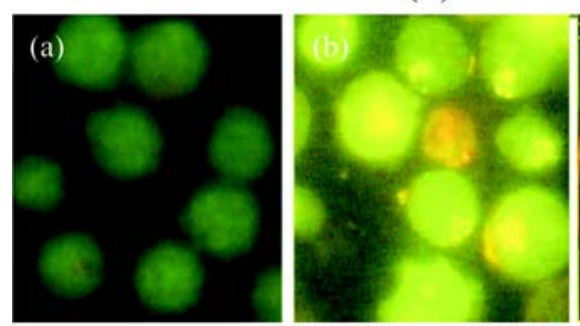

(B)

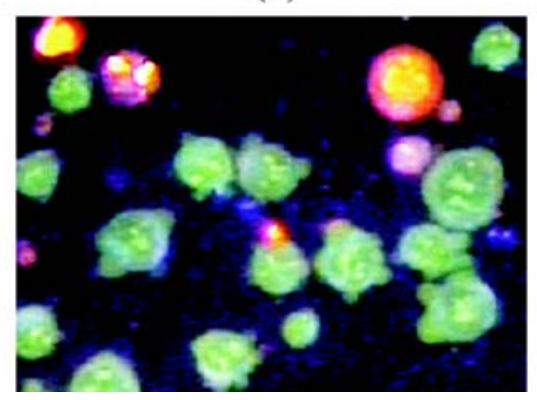

Fig. 6. Fluorescence microscopic analyses of the drug treated K562 and Jurkat cells. K562 (A) and Jurkat (B) cells were incubated with 10 and $7.5 \mathrm{nM}$ of the drug, respectively, along with membrane permeable acridine orange and ethidium bromide which is impermeable to the normal membrane but stain the nuclei of necrotic and late apoptotic cells (orange color). Chromatin condensation and margination as well as ruffling of nuclear membrane are observed. Control K562 cells (a) and drug treated cells after $24 \mathrm{~h}(\mathrm{~b})$ and $72 \mathrm{~h}$ (c). B: drug-treated Jurkat cells after $72 \mathrm{~h}$. Magnification 100×.

synthesis whereas adenosine did not play any role in this respect. However, the addition of hypoxanthine, which prevents the salvage of guanosine to GMP (Vitale et al., 1997), enhanced the drug effects (Table 2). It has been reported that hypoxanthine alone $(100 \mu \mathrm{M})$ dose not have any effects on apoptosis or DNA synthesis of K562 cells (Vitale et al., 1997). These results clearly indicate a role for $3-\mathrm{HK}$ in GTP metabolism. In order to found a link between GTP pool and DNA synthesis, the drug-affected Jurkat cells were treated 
(A)

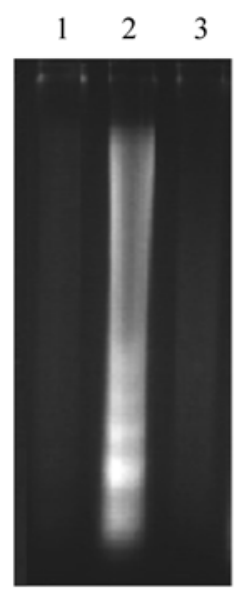

(B)

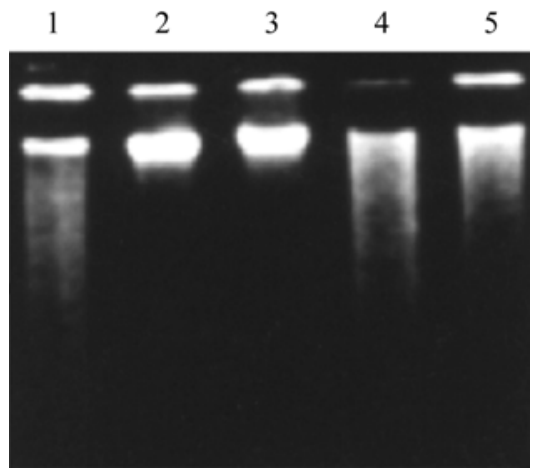

Fig. 7. The effect of $3-\mathrm{HK}$ on DNA fragmentation. The Jurkat cells $\left(5 \times 10^{5}\right.$ cell $/$ well, A) and $\mathrm{K} 562\left(1 \times 10^{6} \mathrm{cell} / \mathrm{well}, \mathrm{B}\right)$ were seeded in microwell plates and treated with 7.5 and $10 \mathrm{nM}$ of the drug, respectively, for $72 \mathrm{~h}$ unless specified. DNA was extracted as explained in materials and methods. A: Lan1, control cell; Lan2, treated cells; Lan3, treated cells plus $25 \mu \mathrm{M}$ guanosine. B: Lan1, 48 h-treated cells; Lan2, control cells; Lan3, $72 \mathrm{~h}$-treated cells plus $50 \mu \mathrm{M}$ guanosine; Lan4, 72 h-treated cells; Lan5, $72 \mathrm{~h}$-treated cells plus $50 \mu \mathrm{M}$ adenosine.

with actinomycine $\mathrm{D}(0.05 \mu \mathrm{M})$ which is believed to block RNA synthesis without affecting DNA synthesis (Cohen et al., 1981). The results showed the DNA synthesis was restored by $79 \%$ (Table 2 ).

Induction of apoptosis by $3-\mathrm{HK}$ in $\mathrm{K562}$ and Jurkat cells Analyses of the drug treated K562 and Jurkat cells by acridine orange/ethidium bromide double staining showed that the new drug induces apoptosis in the cells in a time and dosedependent manner (Fig. 5). Exposure of Jurkat cells to a 7.5 $\mathrm{nM}$ concentration of the drug induced apoptosis in $14 \%, 34 \%$ and $40 \%$ of the cells after 24,48 and $72 \mathrm{~h}$, respectively. The K562 cells, despite their resistance to many anti-cancer agents, were very sensitive to $3-\mathrm{HK}$ and apoptosis was easily observed in these cells, too (Fig. 6A). The appearance of chromatin condensation, nuclear fragmentation and shift from early to late apoptosis are evident in Fig. 6. In this figure, viable cells are uniformly green, early apoptotic cells are green and contained bright green dots in their nuclei as a consequence of chromatin condensation and nuclear fragmentation. Late apoptotic cells incorporate ethidium bromide and therefore stain orange and in contrast to necrotic cells, they show condense and oftenly fragmented nuclei. DNA fragmentation to oligonucleosomes is clearly observed in Jurkat cells $72 \mathrm{~h}$ after a single dose $(7.5 \mathrm{nM})$ treatment (Fig. 7A). However, oligonucleosomes were not detected in the treated K562 cells, although DNA degradation was documented in these cells (Fig. 7B). In both cells, the DNA fragmentation is blocked by guanosine but not by adenosine (Fig. 7A and B).

\section{Discussion}

Many species of Thymelaeaceae family are known to contain toxic and biologically active ingredients of chemically related diterpene esters. Compounds belonging to the daphnane diterpene esters have been shown to possess anti-leukemic activity as apposed to tigliane diterpene esters which are known to be carcinogenic (Kupchan et al., 1976; Evans and Soper, 1978). In that respect, daphnane diterpene esters such as genkwadaphnin, yuanhuacine (Hall et al., 1982; Liou et al., 1982), genididin, giniditrin and genidilatin (Evans and Soper, 1978; Stanoeve et al., 2005) possess significant anti-leukemic activities both in vivo and in vitro with major metabolic effects on the DNA and protein syntheses (Hall et al., 1982; Liou et al., 1982). Recently, a new diterpene ester has been characterized from Dendrostellera lessertii which shows high anti-leukemic activity, in nanomolar ranges (Table 1) compared to micromolar doses reported for some other diterpene esters (Kupchan et al., 1976; Hall et al., 1982; Yazdanparast and Sadeghi, 2004). Concerning this biological potency, a detailed understanding of the mode of action of this active compound should provide useful information concerning its further use in cancer therapy.

The anti-leukemic activity of many diterpene esters is mainly attributed to their inhibitory action toward different enzymes particularly IMPDH (Hall et al., 1982; Liou et al., 1982; Hall et al., 1986). The new diterpene ester, 3-HK, shares similar activity toward IMPDH (Yazdanparast and Sadeghi, 2004). According to our results, the drug at short treatment times (less than $24 \mathrm{~h}$ ) potently inhibited cell proliferation followed by the cell cycle arrest in G1 phase, without significant cytotoxic effects. These means that the drug at low concentrations and/or at low treatment times has cytostatic property rather than cytotoxic effects. However, longer treatment times ( 2 to 3 days) or higher concentrations were required for cell death occurrence. Indeed, post-G1 arrest apoptosis was occurred under drug administration. This matter was further confirmed by morphological and biochemical observations. Condensation and fragmentation of nuclear DNA were demonstrated morphologically by fluorescent 
staining with DNA-binding dyes (acridine orange/ethidium bromide). The biochemical evidence of apoptosis was provided by detecting the DNA fragments which are hallmark of apoptosis.

Reduction of DNA synthesis (Fig. 3) and inhibition of IMPDH activity as reported previously (Yazdanparast and Sadeghi, 2004) under the effect of 3-HK may be responsible for the cell apoptosis as shown for mycophenolic acid and tiazofurin which both inhibit DNA synthesis and induce apoptosis (Jayaram et al., 1992; Vitale et al., 1997; Laliberte et al., 1998). Reduction in GTP and/or dGTP pool size, as a consequence of IMPDH inhibition, might be the main cause of our observation (Jayaram et al., 1999). Restoration of DNA synthesis and the progression of cells through the G1/S checkpoint after guanine nucleotide addition to the drugtreated cells confirm this prediction. It has been shown by Cohen group that exogenous guanosine is salvaged to GTP via guanine by sequential action of several enzymes and further converted to dGTP by ribonucleotide reductase (Cohen et al., 1981). Deoxyguanosine is also salvaged to GTP and dGTP by the same enzymes as is guanosine. However, deoxyguanosine is also directly converted to dGTP (Cohen et al., 1981). Based on this knowledge, if dGTP depletion was responsible for 3HK toxicity and inhibition of DNA synthesis, then exogenous deoxyguanosine seems to be a more effective rescue agent than guanosine. The higher potency of exogenous guanosine in reducing the drug toxicity and enhancing the extent of DNA synthesis (Table 2) suggest that probably the salvage to GTP rather than dGTP is responsible for alleviating the drug effects. The effects of deoxyguanosine on reducing the drug toxicity and enhancing DNA synthesis (Table 2) might be related to its salvage into GTP rather than dGTP. The specific action of the drug on GTP pool was further evident concerning the effect of hypoxanthine on the drug-treated cells which potentiates the drug effects through depletion of GTP pool size (Vitale et al., 1997). Final decision concerning the effect of the drug on the pool size of GTP and dGTP awaits determination of their exact concentrations in the treated cells. Further evidence concerning the manipulations of GTP pool size by $3-\mathrm{HK}$ is provided by the following observation.

Inhibition of RNA synthesis in drug-treated Jurkat cells by $0.05 \mathrm{M}$ actinomycine $\mathrm{D}$ enhanced DNA synthesis by almost $79 \%$ compared to the drug-treated cells. In fact, inhibition of the RNA biosynthetic pathway will reduce the demand for GTP (used in RNA syntheses) and consequently more GTP will be available to be used in DNA synthesis (Catapano et al., 1995).

In conclusion, the results of the present investigation showed that, upon inhibition of de novo synthesis of guanine nucleotides, mainly GTP, in Jurkat and K562 cells by 3-HK, primarily DNA synthesis is inhibited and the cell cycle progression ceased at G1/S checkpoint. These changes finally led to high apoptotic cell death and marginal necrosis at longer treatment times or at higher drug concentrations. In addition, exogenous addition of guanosine to the drug-treated cells, restored DNA synthesis and allowed the cell entry into S phase of their progressing cycle. This observations confirm the effects of the drug on the guanine nucleotide metabolic pathways.

Acknowledgments The authors appreciate the joint financial support of this investigation by the research council of the University of Tehran and the National Research Center for Genetic Engineering and Biotechnology, Tehran, Iran.

\section{Refrences}

Ahmed, N. and Weidemann, M. J. (1995) Biochemical effect of three different inhibitors of purine/pyrimidine metabolism on differentiation in HL-60 cells. Leuk Res. 19, 263-273.

Batiuk, T. D., Schnizlein-Bick, C., Plotkin, Z. and Dagher, P. C. (2001) Guanine nucleosides and Jurkat cell death: roles of ATP depletion and accumulation of deoxyribonucleotides. Am. J. Physiol. Cell. Physiol. 281, 1776-1784.

Catapano, C. V., Dayton, J. S., Mitchell, B. S. and Fernandes, D. J. (1995) GTP depletion induced by IMP dehydrogenase inhibitors blocks RNA-primed DNA synthesis. Mol. Pharmacol. 47, 948-955.

Cohen, M. B., Maybaum, J. and Sadee, W. (1981) Guanine nucleotide depletion and toxicity in mouse T lymphoma (S-49) cells. J. Biol. Chem. 256, 8713-8717.

Earnshaw, W. C., Martins, L. M. and Kaufmann, S. H. (1999) Mammalian caspases: structure, activation, substrates, and functions during apoptosis. Annu. Rev. Biochm. 68, 383-424.

Evans, F. J. and Soper, C. J. (1978) The tigliane, daphnane and ingenane diterpenes, their chemistry, distribution and biological activities. Lloydia. 41, 193-233.

Gu, J. J., Gathy, K., Santiago, L., Chen, E., Huang, M., Graves, L. M. and Mitchell, B. S. (2003) Induction of apoptosis in IL-3dependent hematopoietic cell lines by guanine nucleotide depletion. Blood. 101, 4958-4965.

Hall, I. H., Kasai, R., Wu, R. Y., Tagahara, K. and Lee, K. H. (1982) Antitumor agents LV: Effects of genkwadaphnin and yuanhuacine on nucleic acid synthesis of P-388 lymphocytic leukemia cells. J. Pharm. Sci. 71, 1263-1267.

Hall, I. H., Liou, Y. F., Oswald, C. B. and Lee, K. H. (1986) The effects of genkwadaphnin and genidilatidin on the growth of P338, L-1210 leukemia and KB carcinoma cells in vitro. Eur. $J$. Cancer. Clin. Oncol. 22, 45-52.

Hedayati, M., Yazdanparast, R., Fasihi, H. and Azizi, F. (2002) Anti-tumor activity of Daphne mucronata extract and its effects on TNF- $\alpha$ receptors and TNF- $\alpha$ release in culture human monocytes. Pharmaceutical. Biol. 41, 194-198.

Jayaram, H. N., Gharehbaghi, K., Jayaram, N. H., Rieser, J., Krohn, K. and Paull, K. D. (1992) Cytotoxicity of a new IMP dehydrogenase inhibitor, benzamide riboside, to human myelogenous leukemia K562 cells. Biochem. Biophys. Res. Commun. 186, 1600-1606.

Jayaram, H. N., Cooney, D. A., Grusch, M. and Krupitza, G. (1999) Consequences of IMP dehydrogenase inhibition, and its relationship to cancer and apoptosis. Curr. Med. Chem. 6, 561574. 
Kupchan, S. M., Shizuri, Y., Sumner, W. C., Haynes, H. R., Leighton, A. P. and Sickles, B. R. (1976) Isolation and structural elucidation of new potent antileukemic diterpenoid esters from Ginida species. J. Org. Chem. 41, 3850-3853.

Laliberte, J., Yee, A., Xiong, Y. and Mitchell, B. S. (1998) Effects of guanine nucleotide depletion on cell cycle progression in human T lymphocytes. Blood. 91, 2896-2904.

Li, G., Segu, V. B., Rabaglia, M. E., Luo, R. H., Kowluru, A. and Metz, S. A. (1998) Prolonged depletion of guanosine triphosphate induces death of insulin-secreting cells by apoptosis. Endocrinology 139, 3752-3762.

Liou, Y. F., Hall, I. H. and Lee, K. H. (1982) Antitumor agents LVI: the protein synthesis inhibition by genkwadaphnin and yuanhuacine of P-388 lymphocytic leukemia cells. J. Pharm. Sci. 71, 1340-1344.

McGahon, A., Bissonnette, R., Schmitt, M., Cotter, K. M., Green, D. R. and Cotter, T. G. (1994) BCR-ABL maintains resistance of chronic myelogenous leukemia cells to apoptotic cell death. Blood. 83, 1179-1187.

Metz, S., Holland, S., Johnson, L., Espling, E., Rabaglia, M., Segu, V., Brockenbrough, J. S. and Tran, P. O. (2001) Inosine5 '-monophosphate dehydrogenase is required for mitogenic competence of transformed pancreatic beta cells. Endocrinology 142, 193-204.

Mianabadi, M., Rivera, E. and Yazdanparast, R. (2003) Characterization of a new diterpene ester from the leaves of D. mucronata. J. Trop. Med. Plants. 4, 1-4.

Mianabadi, M. and Yazdanparast, R. (2004) Inhibition of substrate-tumor cell adhesion under the effect of gnidilatimonoein purified from Daphne mucronata. Am. J. Chin. Med. 32, 369-376.

Nio, Y., Imai, S., Shiraishi, T., Tsubono, M., Morimoto, H., Tseng, C. C. and Tobe, T. (1990) Chemosensitivity correlation between the primary tumors and simultaneous metastatic lymph nodes of patients evaluated by DNA synthesis inhibition assay. Cancer 65, 1273-1278.

Papazisis, K. T., Zambouli, D., Kimoundri, O. T., Papadakis, E. S., Vala, V., Geromichalos, G. D., Voyatzi, S., Markala, D., Destouni, E., Boutis, L. and Kortsaris, A. H. (2000) Protein tyrosine kinase inhibitor, genistein, enhances apoptosis and cell cycle arrest in K562 cells treated with gamma-irradiation. Cancer Lett. 160, 107-113.

Pezzuto, J. M. (1997) Plant-derived anticancer agents. Biochem. Pharmacol. 53, 121-133.

Pipaon, C., Gutierrez, P., Montero, J. C., Lorenzo, M., Eguiraun, A., De La Fuente, J. A., Pandiella, A., Leon, J. and Ortiz, J. M. (2002) Mitogen-activated protein kinase routes as targets in the action of diaza-anthracene compounds with a potent growth-inhibitory effect on cancer cells. Mol. Cancer. Ther. 1, 811-819.

Sadeghi, H. and Yazdanparast, R. (2003) Effect of Dendrostellera lessertii on the intracellular alkaline phosphatase activity of four human cancer cell lines. J. Ethnopharmacol. 86, 11-14.

Saydam, G., Aydin, H. H., Sahin, F., Selvi, N., Oktem, G., Terzioglu, E., Buyukkececi, F. and Omay, S. B. (2003) Involvement of protein phosphatase $2 \mathrm{~A}$ in interferon-alpha- $2 \mathrm{~b}-$ induced apoptosis in K562 human chronic myelogenous leukemia cells. Leuk Res. 27, 709-717.

Shu, Y. Z. (1998) Recent natural products based drug development: a pharmaceutical industry perspective. J. Nat. Prod. 61, 1053-1071.

Stanoeve, E., He, W. and De Kimpe, N. (2005) Natural and synthetic cage compounds incorporating the 2,9,10trioxatricyclo[4.3.1.03,8]decane type moiety. Bioorg. Med. Chem. 13, 17-28.

Taraphdar, A. K., Roy, M. and Bhattacharya, R. K. (2001) Natural products as inducers of apoptosis: implication for cancer therapy and preventation. Curr. Sci. 80, 1387-1396.

Vistica, D. T., Skehan, P., Scudiero, D., Monks, A., Pittman, A. and Boyd, M. R. (1991) Tetrazolium-based assays for cellular viability: a critical examination of selected parameters affecting formazan production. Cancer Res. 51, 2515-2520.

Vitale, M., Zamai, L., Falcieri E., Zauli, G., Gobbi, P., Santi, S., Cinti, C. and Weber, G. (1997) IMP dehydrogenase inhibitor, tiazofurin, induces apoptosis in K562 human erythroleukemia cells. Cytometry. 30, 61-66.

Yamada, T., Okajama, F., Akbar, M., Tomura, H., Narita, T., Yamada, T., Ohwada, S., Morishita, Y. and Kondo, Y. (2002) Cell cycle arrest and the induction of apoptosis in pancreatic cancer cells exposed to adenosine triphosphate in vitro. Oncol Rep. 9, 113-117.

Yazdanparast, R., Mianabadi, M. and Abdolmohammadi, M. H. (2003) Anti-tumor activity of Dendrostellera lessertii and the inhibitory effect of one of its purified diterpene ester on wehi164 cell adhesion. Nat. Prod. Sci. 9, 161-166.

Yazdanparast, R. and Mianabadi, M. (2004) The effect of the active component of Dendrostellera lessertii on the adhesive property of human platelets and HL-60 cells. Life Sci. 75, 733739.

Yazdanparast, R. and Sadeghi, H. (2004) Nucleic acid synthesis in cancerous cells under effect of gnidilatimonoein from Daphne mucronata. Life Sci. 74, 1869-1876.

Yoshida, M., Feng, W., Saijo, N. and Ikekawa, T. (1996) Antitumor activity of daphnane-type diterpene gnidimacirin isolated from Stellera chamaejasme. Int. J. Cancer. 66, 268273.

Zhang, G., Tu, C., Zhang, G., Zhou, G. and Zheng, W. (2000) Indomethacin induces apoptosis and inhibits proliferation in chronic myeloid leukemia cells. Leuk Res. 24, 385-392.

Zimmermann, A. G., Gu, J. J., Laliberte, J. and Mitchel, B. S. (1998) Inosine-5'-monophosphate dehydrogenase: regulation of expression and role in cellular proliferation and $\mathrm{T}$ lymphocytes activation. Prog. Nucleic. Acid. Res. Mol. Biol. 61, 181-209. 